Institute of $\mathbf{F}_{\text {ood and }} \mathbf{A}_{\text {gricultural }} \mathbf{S}_{\text {ciences }}$

\title{
Average Nutrient Content and Bulk Price of Byproduct Feeds Commonly Available to Florida Cattle Producers ${ }^{1}$
}

John D. Arthington ${ }^{2}$

Table 1. Average nutrient content and bulk price of byproduct feeds commonly available to Florida cattle producers ${ }^{1}$

\begin{tabular}{|c|c|c|c|c|c|c|}
\hline Byproduct & DM & TDN & $\mathrm{CP}$ & $\mathrm{Ca}$ & $P$ & Price \\
\hline & ----\%---- & \multicolumn{4}{|c|}{ 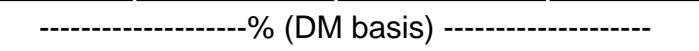 } & $--\$ /$ ton -- \\
\hline Broiler litter & 81 & 50 & 24 & 2.30 & 1.60 & ----- \\
\hline Corn gluten feed & 90 & 83 & 25 & 0.36 & 0.82 & $\$ 95$ \\
\hline Corn gluten meal - 45 & 91 & 84 & 46 & 0.16 & 0.51 & $\$ 265$ \\
\hline Corn grain & 88 & 90 & 10 & 0.02 & 0.35 & $\$ 115$ \\
\hline Cottonseed meal - 49 & 92 & 75 & 49 & 0.20 & 1.10 & $\$ 160$ \\
\hline Cottonseed & 92 & 92 & 23 & 0.16 & 0.70 & $\$ 165$ \\
\hline Distiller grains ${ }^{2}$ & 94 & 86 & 23 & 0.11 & 0.43 & $\$ 125$ \\
\hline Molasses (sugarcane) ${ }^{3}$ & 75 & 72 & 5 & 1.00 & 0.11 & $\$ 65$ \\
\hline Peanut hulls & 91 & 22 & 7 & 0.26 & 0.07 & ----- \\
\hline
\end{tabular}

1. This document is AN142, one of a series of the Animal Sciences Department, Florida Cooperative Extension Service, Institute of Food and Agricultural Sciences, University of Florida. Original publication date April 29, 2003. Visit the EDIS Web Site at http://edis.ifas.ufl.edu.

2. John Arthington, assistant professor, Range Cattle Research and Education Center, Cooperative Extension Service, Institute of Food and Agricultural Sciences, University of Florida.

The Institute of Food and Agricultural Sciences is an equal opportunity/affirmative action employer authorized to provide research, educational information and other services only to individuals and institutions that function without regard to race, color, sex, age, handicap, or national origin. For information on obtaining other extension publications, contact your county Cooperative Extension Service office. Florida Cooperative Extension Service/Institute of Food and Agricultural Sciences/University of Florida/Christine Taylor Waddill, Dean. 
Table 1. Average nutrient content and bulk price of byproduct feeds commonly available to Florida cattle producers ${ }^{1}$

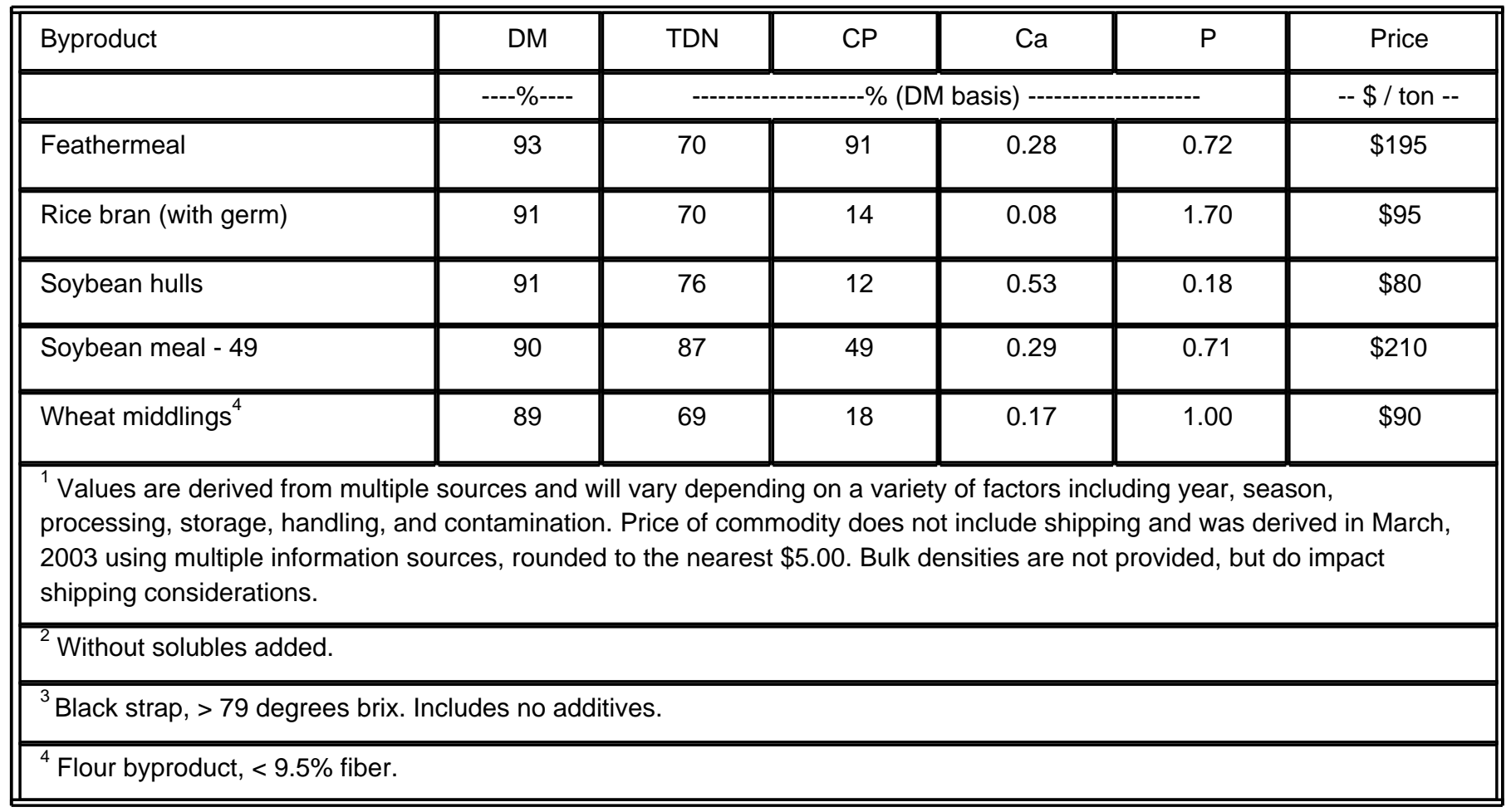

\section{Attention County Faculty:}

Please remember that commodity feeds do not come with a guaranteed nutrient analysis. Storage and handling costs will often offset savings derived from commercial feed/supplement replacement. All faculty interested in up-to-date information on commodity feeds should obtain a copy of:

Alternative Feeds for Beef Cattle

In: The Veterinary Clinics of North America

- Food Animal Practice

Editors: G. M. Rogers and M. H. Poore

W. B. Saunders Company, Philadelphia

Volume 18:2

First Edition, July 2002 